\title{
Under the Empire of Spontaneous Solidarity: State and Political Action in the Theoretical Durkheimian Project (1892-1893)
}

\author{
Graciela Alejandra Inda ${ }^{1}$ (1)
}

\begin{abstract}
This paper aims at identifying and examining all the principles arisen from the issues of the state and politics in Durkheim's production during the period 1892-1893, signaled by the publication of his famous thesis on the cohesive role of the division of social labor. According to the in-depth analysis carried out in this article, the most important points of Durheim's politics are four. Firstly, the conception of the state as an organ that translates an automatic social solidarity because it is an entire entity preexisting any political relationships. Secondly, the distinction of despotism as a regime that implies the complete absorption of individuals by the political apparatus. Thirdly, the problem of the growing enlargement of the state interventions in the individuals' private life sphere. Finally, the incapacity of any political action to transform the society's morphology.
\end{abstract}

\section{Keywords}

Durkheim • 1892-1893 • State • Politics • Solidarity

\footnotetext{
1 Correspondence to: Graciela Alejandra Inda, IDEHESI/CONICET-IMESC Facultad de Filosofía y Letras. UNCuyo. Centro Universitario, Ciudad de Mendoza, Mendoza 5500 Argentina. Email: gracielainda@hotmail.com ORCID: 0000-0003-2139-7310

To cite this article: Inda, G. A. (2019). Under the empire of spontaneous solidarity: State and political action in the theoretical Durkheimian project (1892-1893). Istanbul Üniversitesi Sosyoloji Dergisi, 39, 65-84.
}

https://doi.org/10.26650/SJ.2019.39.1.0015 
With the purpose of seeking a balance, Ottonello (2016) classifies the different interpretations that have dominated Durkheim's reception into four distinct groups: close collaborators who continued, spread and compiled his work (Davy, Mauss, Bouglé, Fauconnet and others between 1920 and 1940); collaborators' disciples who continued the study of other cultures while criticizing the main theoretical Durkheimian principles (Lévi-Strauss, Dumézil, between 1930 and 1980); new theoretical sociologists (Parsons, Giddens, Habermas, between 1930 and 1980); and those people in charge of detailed historiographical studies (Lukes, Besnard, Hirst, Karady, Tiryakian, Bellah, 1970 up to now ${ }^{2}$ ).

In this heterogeneous set of viewpoints, examining the specific form of the political dimension of different social processes does not occupy a prominent place in the Durkheimian project. ${ }^{3}$ Derek (1991) dares to say that Durkheim's observations to the modern state and politics have been obviously dodged.

Even though they constitute a minority, there are some valuable analyses in specialists' literature not in tune with the hegemonic topics- (Birnbaum, 1976; Filloux, 1977; Giddens, 1986; Lacroix, 1981; Hawkins, 1981), which throw light on some unattended aspects of the Durkheimian political sociology.

To the rejection that a Parsonian interpretation generates of Durkheim's work as a sociology of order, controversies of the value and the limitations of his political theory can be added. Other interpretations consider this theory suspicious of an organicism tending to strengthen the state leviathan and they enter in dispute against those that highlight that it is the human being the one who limits the power of the State. Interpretations that praise its capacity not to remain caught in the narrowness of political phenomena with the purpose of sinking its roots in structural analysis, run counter to those that criticize its dismissal of the political institutions themselves. Those interpretations that recognize an important explicative potential in his theory are contradicted by those readings that consider it as a doctrine that conserves social control.

There exist some debates on the importance or not of differentiating stages or moments with different purposes. Lacroix (1981) claims that in Durkheim's work published in 1893 he does not present any further conceptualization because he presents his characteristic idea of absolute determinism together with the possibility of action and the autonomy of collective representations. In this sense, Alexander (1982) considers that all the issues related to his thesis in 1893, which put a lot of emphasis on social structure and density, should be distinguished from the ideas in

2 It is also worth saying that the latest biographic work on Fournier's life (2007) complemented all the classical studies which attempt to illustrate Durkheim's intellectual trajectory.

3 The absence of Political Sociology in the Durkheimian classification of social sciences, pointed out by Favre (1982), constitutes undoubtedly one of the reasons that accounts for this disdain. 
The Elementary Forms of Religious Life, by means of which he tries to account for the effervescence of social action. On the contrary, Giddens (1979) puts forward that the postulates presented in the text regarding division of labor are not meaningless phrases. He adds that they are general frameworks in which all the rest of his texts could be placed. Also, Filloux (1977) y Joas (1993) highlight the unity and coherence in Durkheimian theorical project.

The purpose of this article, clearly located in the field opened by the aforementioned analyses, is specifically identifying the thesis and conceptual apparatuses that emerge from the issues of the state and politics in Durkheim's production between 1892 and 1893.

In this short but productive period, the center of the scene is occupied by the problem of the cohesive function of division of social labor in modern societies. However, this does not prevent him from developing important definitions on the political action and on the modern state, its functions and its fields of action. All this will be shown next.

It is worth mentioning that the years $1892 / 1893$ which are the focus of this analysis must be considered as a continuation of some problems that began to emerge by the middle of the previous decade.

In Durkheim's earlier interventions, asking about the role that the state played in the national integration of a nation was one of his main enquiries ${ }^{4}$. However, it must be assumed that as Durkheim came into contact with intellectual activity in German universities, he appeared to be more and more convinced of the inability of political power to bring all individuals together in an everlasting nation.

In fact, in the review Les études de science sociale (Durkheim, 1886), he asserts that those who claim that there is no law or moral before the appearance of the state are mistaken because they have both existed since men have lived side by side. Political bodies themselves cannot generate social cohesion, rather they reinforce, order and apply moral rules (these do have integrating strength) which are inscribed in the nature of social life. Therefore, no everlasting collectivity can emerge from individuals who are joint together by external impositions.

A society is not a collection of individuals who are kept together by means of an enormous and monstrous machine. This is not a society. Solidarity comes from inside, not outside. Men are joint together naturally like the atoms of a certain mineral or the cells of an organism. (...)

4 Even though there are more advances in the field of the enquiries than in the actual production of concepts, in some bibliographic reviews, speeches and courses carried out by Durkheim between 1883 and 1885, it can be noted an argumentative line according to which the cohesion of a nation, the main problem that moves him into reflection, depends at the same time but in different degrees on the pressure of the social moral and the behavior of an state understood as being the directive strength that rules and combines all the basic movements. For further analysis of this period, see Inda (2007). 
At all times in a society's development, said solidarity is expressed externally by means of an appropriate structure. The state is one of these structures. The state is the external and visible form of sociability (...). (Durkheim, 1886, p. 212)

According to the young Durkheim's words (1887a), a lack of national union requires constituting a new moral and teaching it: this is what he learnt from German professors. Professors' work must be civic, it must be useful to defend the nation, to enforce laws and to fight against individualism, which is the source of dissolution of all and any national bounds.

If moral authority is the driving potency that joins all the individuals together in a nation and the antidote against the anarchy which would rule if people give up to their selfish appetites, the state is responsible for transmitting the precepts of a moral and secular education (Durkheim, 1887a).

In the text La science positive de la morale en Allemagne 5 (Durkheim, 1887b), he goes further in his argumentation and he claims that the state is in charge of exerting its force to achieve the application of Law whose principles come from the inherent customs of collective life. However, he still points out that the coercion that is centered on the state is not enough to guarantee the compliance of the rules, as its legitimacy depends on the fact that this coercion is supported by collective feelings. He rejects the proposal of the German "Sociologists of the Chair" to define the moral principles of an state's action that fosters a fair distribution of social richness since he is firmly convinced that legal rules are not the result of a mere political action as legislators illustrated it.

He insists on the idea that the energy of the state lies in its capacity to represent common beliefs and feelings transmitted from generation to generation and that they carry a compulsory strength for all and any wills (Durkheim, 1888).

It is worth noting that in Durkheim's viewpoint, the state is a superior power to individuals, and as any other social phenomenon, it is so, in the sense that it is previous to them and it does not depend on their wills. However, this superiority cannot be considered as a possibility for the state to coercively interfere in the individuals' lives and absorb them. In fact, this interference is typical of despotic states.

5 This decisive text in the trajectory of Durkheim's thoughts constitutes an exposition in front of French social philosophers about the progresses carried out by economists and jurists in the constitution of a positive science of moral. Here, he analyzes the approaches of the "sociologists of the chair" Wagner and Schmoller, Schäeffle's work, the theory of the jurist Jhering and professor Wundt's moral theory. In general words, it can be said that beyond certain specific criticisms, he rescues from these thinkers their insistence on considering the rules and moral actions as phenomena of social organization. He also takes from them their idea that a moral obligation is social in its origin and its nature, their criticism against orthodox economists based on an individualist utilitarianism, their aspiration to transform the study of moral into a positive science and their consideration of a society as something irreducible to the individuals, with its own strength. 
A bit later, moved by reading Tönnies, Durkheim (1889) puts emphasis on his conclusion of 1886 related to the interiority of social solidarity and he insists that the regeneration of social tissues mainly depends on a moral attraction rather than on the force of the state.

To sum up, all the concepts presented by Durkheim in his famous texts of 1892 and 1893, come from an activity of going more deeply and precisely on some former readings and enquiries as it will be shown later. In them, it can be appreciated that the issue of social solidarity is transformed into the departing point of a moral science and in a key problem that articulates all the other topics, including those from the state and the exercise of politics.

\section{Legislators as Customs Translators}

In his latin thesis on Montesquieu, Durkheim concludes that an appropriate classification of societies cannot be limited to the forms of government, as morality, religion, commerce and family are the elements that express its essential nature, forming the true matter of social sciences.

If at first sight Montesquieu's classification seems to depend on the number of governors and the form of administration of public affairs; an attentive look shows, according to Durkheim $(1892 a)^{6}$, that Montesquieu considers society as a whole; that is, the number, the disposition and the cohesion of its elements.

Different from a monarchy ${ }^{7}$, that corresponds to societies where social division of labor is well-developed, the Republic, especially in its democratic form, can be displayed in societies composed by similar members, even in their fortunes and private lives, who are linked and juxtaposed by the same bonds among themselves. Political positions and magistrates are occupied for a fixed period of time and they do not imply a superior position (Durkheim, 1892a).

6 Besides the referred French text, the recent version called Montesquieu by Watts Miller y Griffiths can be usefully consulted Quid Secundatus Politicae Scientiae Instituendae Contulerit which includes an English translation of the original Latin text as well as criticisms, corrections and explanations about the decisions made by the translator. It also presents an essay written by Watts Miller (1997) where he discusses the importance of his Latin thesis as a text about the nature of causality, the method and a comparative analysis, together with The rules of sociological method, these two texts must be read in order to understand the Durkheimian project.

7 Montesquieu claims that in monarchies we can prove the formula according to which power stops power, as the different organs of the social body limit the prince authority at the same time they stop each other reciprocally. The diversity of functions and its consequent persecution of personal interests are the source of cohesion in this type of societies. Believing that they are just pursuing individual advantages, they are unconsciously pursuing the common good, as honor is the basis of public life. A despotic state constitutes a degradation of the other forms. This takes place when in a monarchy, there does not exist any labor division, being differences abolished or when in a democracy, every citizen is the same in serfdom. Here, the basis of the political life is to be afraid of the prince (Durkheim, 1892a). 
He does coincide with Montesquieu that loving your nation and state more than yourself is the basis of a Republic; but Durkheim (1892a) does not consider that this political virtue is the result of the fact that there exist laws that prohibit few people's enrichment - and with this, having large distances between fortunes- since laws do not have the power to originate common good.

In spite of all his merits, the classification made by the author of De l'esprit des lois implies, from a Durkheimian perspective, an overestimation of the legislators' roles and of the political ${ }^{8}$ authority in general.

In Montesquieu's viewpoint, the legislator plays a fundamental role in every social organization in forging the laws that rule it. Opposite to the spontaneous customs emerged from collective life, laws require from a political will capable of examining society nature to distinguish its goal and the appropriate means to achieve it. Although laws cannot be arbitrary, and they must recognize the rooted customs of a society, they cannot exist without the creative and crucial intervention of a legislator.

However, Durkheim (1892a) considers that laws are not mainly the result from the legislator's task but that they come from customs. Laws are the same as customs, sometimes unconscious and obscure, defined and expressed in a clear way. When writing a law, the legislator acts as a tool for causes that exceed him completely.

Law does not need primarily anything from the State or from its forms of organization. It is not based on an external and artificial coercion but on an inner feeling, that is, the individual interdependence in the fight for existence and in the solidarity that joins them. The State, once formed, can regulate the execution of laws but do not constitute the law. Crimes, for example, are a natural fact whose conditions lie in the nature of the society itself and it does not depend on the will of the State men (Durkheim, 1893a).

Some of the most distinctive statements presented in De la division du travail social are already drafted in former efforts and as Lacroix (1981) points out: reading Montesquieu from a critical perspective paves the way to analyzing the different forms of solidarity.

8 Even though he considers Montesquieu slightly exaggerates, Durkheim (1892a) values the key role Montesquieu provides to the inherent conditions of the nature of the societies (soil nature, size of population, weather conditions) in the definition of types of societies and the forms of the state. Considering the governing regime together with other characters of societies, he contradicts the restricted classifications based exclusively on political factors. 
In effect, in this famous work, Durkheim (1893b) defines law as a visible symbol that expresses collective ${ }^{9}$ will and he insists on the idea that the state organ in charge of dictating and applying law is a mere vehicle for said will. Although men working with laws play an organizing and clarifying role of diffused customs, they can neither act to their own judgements nor go against rooted collective feelings.

\section{The Forms of State as a Reflection of the Forms of Solidarity}

Towards 1893, the queries about the State and its political action, framed with insistence and emphasis on the previous decade, started to bring about precise conceptual effects.

Paradoxically, while the problem of the State leaves the center of the scene because Durkheim becomes certain that it does not have an own power but delegated in the maintenance of social cohesion; his formulation gets more precise and full of answers, not necessarily definitive ones, by the way.

How he deals with politics and State's nature, its functions and its historical forms, although secondary, is absolutely full of details in some aspects. In effect, a careful reading of the three books that make up De la division du travail social ${ }^{10}$ makes us recognize a series of statements and principles that show a deeper complexity in his conception of State in general, and of Modern State in particular.

At first, we must point out that the thesis according to which the State is born in the society and expresses its degree of solidarity, which started to be developed in the last decade, acquires now more definitive edges than before.

From analyzing the genesis of punishment, Durkheim argued in favor of the historical precedence of society, or more exactly, of the social solidarity, in respect of the State.

The function of a court is firstly performed by the whole community met in an assembly who reacts as a unit, because even though the punishment is not fixed yet accurately, the crime is immediately recognized because it insults strong and defined states of the collective consciousness. When the assembly takes a long time to

9 As it is well known, he distinguished two types of law: repressive law based on revenge, typical from societies where mechanic solidarity prevails, with a strong collective consciousness, which is extended and mainly with a religious character. The other type is the restitutive law, made by rules that pursue recovering disrupted relationships, corresponding to societies mainly bound by an organic solidarity due to the social division of labor.

10 It can be checked in the English edition carefully done by the well-known specialist Steven Lukes published in 2014 by Palgrave Macmillan editorial. Apart from being a revision of the original translation, in charge of W. D. Halls, it includes Lewis Coser's introduction from 1984 and a presentation of the above-mentioned Steven Lukes who studies the most important theorical concepts of this work in its specific historical circumstances. 
embody a boss or a government organ, it is the nature of the collective feelings what explains both, the punishment and the crime (Durkheim, 1893b).

If the State expresses the social life, therefore, different types of states correspond to each type of society. This is the thesis that appears veiledly on Durkheim's pages devoted to differentiating societies that are kept cohesive around the similarities of their members who base their integration on the social division of labor.

In those societies whose social structure corresponds to a mechanic solidarity, it is common that the intense dependence that individuals have of the common consciousness is transmitted to the boss or central authority who embodies this role. The directing power that the controlling organ can reach in this type of societies is due to the fact that it conforms an emanation from the collective consciousness. What is more, in these conditions, the action of this collective consciousness can reach a maximum energy as it stops being diffused and it is channeled through a definite organ (Durkheim, 1893b).

Meanwhile in the societies with a predominance of organic solidarity, formed by organs, functionally different and with an inner differentiation, coordinated and subordinated to each other, the central organ does not bear an absolute power, but it only performs a moderate and temporary action. While there is some mutual dependence among the different organs, there are only differences in grade and none of them bears an absolute power ${ }^{11}$ (Durkheim, 1893b).

Without being explicitly stated, we can recognize two types of relationships between the state and the individual which each of them is staged over a type of society. On one hand, there is a despotic or absolutist relationship that corresponds to primitive or old societies with a centralized power, tending to have a mechanic solidarity. On the other, there is a relationship which can be called organic or functional as Durkheim does not use any precise qualificative adjective for this type of relationship.

We can read between lines in Durkheim's speech that he makes the following conclusion: with a historic development, the state organ gets less and less despotic as a preponderance for organic solidarity grows because of an expandable division of social labor. The existence of differentiated organs and the dependence generated between them by the social division of labor prevents an excessive exercise of collective authority embodied by the state organs.

11 It's worth saying that in Chapitre 7 you can find a definition of the state organ as a brain that leads the relations of the different social organs and it rules over every element or component. However, we must point out that this faculty which empowers the state to direct plays a marginal role because we can not make any precise conceptual interpretation or analogies. The most important concept he formulates is the one that considers the state as an intermediary and translator of the collective consciousness. 
In other words, the nature of authoritarian governments comes from a social type determined by a state of homogeneity that leaves almost no room for individual life and that individuals are submitted to the state authority in the only way they know how to do it in this social type, by a complete determination, in an absolute way. With an advance of individualism, typical from social types which are closer in time, this form of despotism moves back and tends to disappear. ${ }^{12}$

\section{The State as a Reinforcement of the Collective Consciousness}

Even coming from the power that is diffuse in the society, the power of reaction that governing functions bear, once they have appeared, has as a primary and main function to guarantee the respect for beliefs and collective practices, in particular, as Durkheim states (1893b), to defend common consciousness against internal and external enemies.

How successful the state power can be in this crucial endeavor depends -according to a circular reasoning- on the capacity it has to become an exceptional embodiment of the collective type, a supreme representative of the collective strengths from where it gets its force.

The two modalities by means of which the state performs a function of strengthening common life, as we can infer from his thesis in 1893, consist on clarifying diffuse states and obscure social feelings that are part of the collective consciousness and on suppressing opposing social forces despite the society fails to feel their dangerousness.

Let's go back to the circle. The closer and more dependent the state apparatus gets to the collective consciousness and more attention pays to the survival of said consciousness, the more capable it will become to anticipate (standing for certain acts as crimes) or to decipher their needs (regulating diffuse social customs) and to foresee and repel any attacks against this collective consciousness.

\section{The Extension of the State Sphere in Modern Societies}

While arguing with spencer's utilitarianism, Durkheim specifies his definition of a modern state from the analysis of a question that keeps him awake from childhood: is social harmony absolutely spontaneous, or does it need any type of political intervention?

12 Lately, different texts connecting Durkheim's work to the republican tradition have been highlighted. In France, Nicolet (1982), Rosanvallon (2004), and Spitz (2005) are works that should be mentioned, among others. In the United States, Bellah (1973), Cladis (1992), and Challenger (1994), are works that must be specially pointed out. According to Spitz, for example, Durkheim must be considered as a republican because of the fact that he has always rejected the mystic solution that confers to the state other objectives rather than safeguarding and constituting individual rights. Cladis also illustrates this when he claims that Durkheim must be considered as "a classic republican within Tocqueville's tradition" as he promotes a moral individualism as a common faith that supports dignity and the individual's rights and a plurality of spheres that allows diversity and individual autonomy (Cladis, 1992, p. 164). 
In spencer's industrial societies, as individual activity grows and free trade increases, contractual relationships become widespread and solidarity turns automatic as the result of the spontaneous agreement of individual interests. Social relationships, mostly economic (exchanges, contracts) do not need any sort of regulations as they depend on the free initiative of the parties. That is how, the lose both, power and the scope of authority.

Durkheim denies sharing this belief as he considers that the stability of societies where the division of social work has been extended would be in danger if it were based on an individual interest, which only creates superficial and temporary bonds. If selfishness cannot be restricted, we can only expect conflicts.

Besides, from his viewpoint, spencer's ideas are not grounded on historical research. Social discipline has not been relaxed with the passing of time, it has only changed its form. Repressive law (criminal law) has lost ground while restitutive or cooperative laws have been developed intensely (civil, commercial, administrative, constitutional, etc.). The rules and practices tending to achieve uniformity are not numerous anymore as the forms of social discipline that rule complex social relationships have been multiplied among different social functions (Durkheim, 1893b).

It cannot be denied that contractual relationships are multiplied together with labor division, but non-contractual relationships are also developed, and a growing state intervention is present in them. Marriage, for example, is not contracted freely but the Church or a civil authority must intervene at the same time that more formalities are needed to celebrate this ceremony. Adoption conditions have also been multiplied through history. In short, obligations at home get more and more numerous and they get a more public character. Ruling organs must intervene to perform a moderating action on families because the family became an organ with specific functions and what takes place within a family may affect the rest of the society. ${ }^{13}$

In contracts, you can also see the state action because they always follow regulations as a result of social experience and tradition ${ }^{14}$. The role of society is not reduced to witness a free contract execution, but it intervenes in order to avoid contracts altering

13 In the course about the family that he gives in Burdeos, this theme is exhaustively developed. Durkheim (1892b) establishes that the intervention of the state is the condition of a possible transformation of the patriarchal family into a conjugal family, since without that intervention the family ties based on the marriage would brake easily. At the same time, the state has become a factor of domestic life while it intercedes when the father authority exceeds certain limit, it protects orphans and it establishes, in certain cases, the loss of the parental rights, etc.

14 Durkheim revives from Schmoller the idea that the economic relations are always subject to customs and law regulation, that do not consist, therefore, on an abstract exchange between individuals (Durkheim, 1887). 
the regular functioning of certain organs, to guarantee that justice is respected, to apply general rules in specific cases and to prevent social harmony to be at risk. ${ }^{15}$

Despite the ambiguous terms that he used in these sections ${ }^{16}$ (social action, social intervention, public power), we can assure that he is talking about the growing intervention of the state organ that dictates the laws and regulations, enforces and penalizes their breach. Obviously, together with this organized and defined pression, you can find all the obligations imposed by customs that have not been penalized yet by law.

To sum up, from a position trusting in historical progress, Durkheim believes that not only is modern state less despotic than in the past but also it is characterized by an extension of its intervention in social relationships known as private, in a movement that does not generate any contradictions.

\section{The Impotence of the Political Power in the Face of the Capitalist Crisis}

When in his masterpiece published in 1893, Durkheim argues that it is the division of labor which plays ever more the integrating role that a strong and extended common conscious played before, he suggests certain unease. In fact, the division of labor in the capitalist societies does not generate solidarity but conflicts ${ }^{17}$. How does he "solve" this issue? By making a shif: if the division of labor does not originate solidarity, we are before an abnormal situation, consequence of the pathologic forms that it has assumed momentarily.

The two main abnormal forms in which the division of social labor does not produce solidarity are the anomic division of labor (that occurs when the growing specialization relegates the individuals to isolated and meaningless employment, in which each one does not take into account the common task, thus, turning into a source of disintegration) and the forced or coercive division (the one that is imposed to the individuals without taking into consideration aptitudes, abilities and hereditary dispositions). ${ }^{18}$

In normal conditions, the necessary rules for the development of the functions come from the division of labor, more precisely, they come from a sufficient and extended

15 Simultaneously, against socialists, he puts forwards that the state must not perform economic functions, that is, it must not devote itself to the production, planning, or implementation of different reforms. The state reforms that pretend to redistribute the wealth, only alter the natural functioning of the social mechanisms and, besides, they do not work to reduce inequalities.

16 Sections I and II from Chapter VII (Durkheim, 1893b).

17 As it is known, the theoretical and political production of Durkheim takes place in a turbulent France for decades by the economic transformations involved by the consolidation of capitalism, by the popular struggles and by the bitter political struggles between the different capitalist fractions in order to achieve the hegemony in the state apparatuses and to impose the form of organization of the political power.

18 In what follows, the analysis is based on the extensive developments presented by Durkheim in Chapters 1 y 2, Book III (Durkheim, 1893b). 
contact between the different organs. Despite not producing mutual interdependence, they express it in a clearly defined way, their existence is vital, mainly when the functions are more specialized, and their organization is more complex, since when the mutual obligations are not regulated, or they are regulated in an inappropriate manner (anomic state), they lead to conflicts and situations of uncertainty that obstruct the harmonious development of the functions.

Can the state in an anomic situation impose certain rules or regulations to get out of it? Can it improve the contact between the different economic functions?

Comte, with whom Durkheim argues openly about this matter, considers that as the variety of functions, and therefore, of feelings and interests, does not arise spontaneously the required unity, the state is responsible for the special function of constituting and keeping it.

Diametrically opposed to this position, Durkheim insists and maintains his conviction: the spontaneous consensus of the parties (or internal solidarity) is the necessary condition of the regulatory action of the superior centers. In order to have a direction of the whole on the parties, it is essential that the whole does exist, that is to say, that the parties should already be supportive to each other. If the division of labor does not produce solidarity, it is because its conditions of existence have not been conducted yet.

To Durkheim, it is a problem of unbalanced temporalities: when the economic transformations occur with extremely rapidity, the spontaneous but slow balancing processes of conflicting interests and of configuration of a set of customs cannot be displayed. Later on, if they are taken into the state apparatus, they become rules of law.

The solution imagined by Durkheim for the abnormal and exceptional problem of the anomic division of labor does not consist on giving an extraordinary power or special functions to the state. It would be useless. The moral uniformity cannot be maintained by force and it does not respond to political initiatives. At critical moments, the state officials and the political forces also act as translators.

The legal indeterminacy that prevails in the economic world, for example, in the relationships between the worker and the employer cannot be solved by a sovereign action of the state or by a program or political action. Only when a worker, instead of being isolated, acts in relation to the other workers and knows clearly the ultimate aim of his tasks, only when each function has constant relations with the others, the legislation will be able to promote solidarity.

In other words, the anomic crisis can only be overcome when in the division of the social labor the cooperation is set up, that is, when it began to function normally by 
its own inertia. There is no action or political force -that Durkheim always defines as external- that can intervene in this process.

The treatment that the coercive division of labor receives, confirms the preceding conclusion. This abnormal situation in which the inferior classes (such is the term Durkheim uses), discontented with the role that custom and law have assigned to them, aim to perform functions that are prohibited for them, does not come from the division of labor but, on the contrary, from the use of state coercion.

When the division of labor is imposed from upper classes and coercively, in a more or less violent manner, the distance between interests, individual aptitudes and their daily occupations are experienced as a suffering because they do not respond to "natural talents". And in this way, you only achieve an imperfect and disturbed solidarity.

Only the spontaneity guarantees a division of labor that corresponds to the variety of abilities, that is, a division in which more competent individuals for each type of activities, can reach them. The coercion begins when a regulation, a right, instead of responding to natural talents and customs, it is based on force, and when the political power tries to change the existing inequalities, that is to say, when it seeks to alter the conditions in which the attendees dispute the functions.

Neither the state nor political forces, in short, must intervene in the development of that competence through which the different economic functions are distributed. They must also be careful to accept their results, even if they may seem unfair.

According to Durkheim, the only functions that correspond to the different state instances consist of materializing in rules, those habits and customs emerging from the nature of society (it should be understood as a field of dispute to perform the different social functions); of safeguarding (accessorily) the maintenance of the undertaken commitments ${ }^{19}$ and of abstaining from modifying the rules of competition favoring certain workers to the detriment of others (the contracting parties, for example, must be in equal conditions and none must receive external help, only in this way, the unequal situations in the society are limited to clarify the internal inequalities ${ }^{20}$ ).

\section{Socialism as a Commitment towards a Moralizing State}

In his article of 1893 dedicated to study scientifically the socialist doctrine, Durkheim establishes that in its diverse variations, from the revolutionaries to

19 Accessorily, because according to Durkheim, the public authority is not enough to maintain the contracts and it is essential that they be supported spontaneously.

20 It is necessary to take into account that for Durkheim the coercion does not derive only from the state, though it is the main way. For example, if a class is obliged to accept whatever price for its services, thanks to the fact that another class owns the resources and not due to some social superiority. In this case, it can be said that there is coercion of the second class on the first one. 
teaching socialism, it is characterized not only by the plan of changing the current economic state but also by asking for a state regulation of the economic functions.

Emerging from a society with a division of labor increasingly marked, socialism expresses for Durkheim (1893c) an undeniable and clear necessity: the industrial and commercial functions, in order not to be diffuse, must be organized by the state.

Unlike communism, that corresponds to a historic stage of social indifference, socialism, that is, the demand of an increased intervention of the state in the economy, is consistent with more developed societies, composed of multiple and autonomous organs but interdependent between them. What does the intervention, that Durkheim agrees with, involve? It involves subordinating the individual purposes to the really social purposes, that is to say, moral (1893c).

We cannot fail to notice that there has been a discrepancy regarding the function attributed to the state. If on the pages referred to the moral function of de division of labor, it is unable to regulate the complex diversity of the economic functions of the modern societies, in his notes about socialism, there appear as an instance (not at all exclusive) of moral organization of the economic world. This second perspective, indeed, is emphasized in his immediately subsequent writings.

A few years later, in a situation of resurgence of the socialist thinking in France, in the midst of which some of his students begin to enlist (Lukes, 1985), Durkheim comes back to this issue ${ }^{21}$, and he continues claiming the connection between the diffuse economic functions with the consciousness and directing centers of society ${ }^{22}$.

He also confirms that socialism, emerged from the collective necessities, does not consist of placing the economic life in the hands of the state but of establishing a polished and permanent contact. In a socialist system, Durkheim will point out (18951896), the state will lose its specifically political character to focus on the direction and administration of the economy. The situation of the non-capitalist laborers and the workers, for example, can only improve through its approach to the centers that lead social life.

In other words, for him, the main component of socialism is not the workers' demands, or the negation of the individual property, or the despotic subordination of

21 Between 1895 and 1896 in Burdeos, he gives a course about the history of socialism (published only in 1928) that expected to continue a few more years to cover the conceptions of Fourier, Proudhon, Lassalle and Marx, but finally it remains unfulfilled. He will always regret not having finished his history of socialism (Mauss, 1928, p. 38).

22 Durkheim (1895-1896) uses this expression instead of the word "state" deliberately. If the theorists of socialism suppose that the capitalist state, as we know it, will disappear to become the center of the economic life, this instance of organization that is still standing up cannot be called with the same name. 
the individual, or the class struggles: it is the conception of a conscious reorganization of the economic life.

In his particular analysis of the socialist thinking, Durkheim transforms a structural economic problem in a moral one, that is to say, a lack of integration. At the same time, the state appears clearly to be placed above and aside the classes: it is the representative of the general interests of the society. Only in that way, it can perform its moderating role. The hypothesis of the state as an instrument of class domination, that prevents any vision of the state as a neutral arbitrator of the class conflict, is completely excluded by the sociologist.

An anthropological philosophy enters into scene to support the Durkheimian discourse: if the human appetites do not find a brake, a discipline, we can only expect social disorder and individual anxiety. For each individual to be content with his fortune and not to ask for more money than can be expected, it is necessary the existing of a moral authority, of a regulating influence.

There is no doubt that social functions, including the economic ones, need to be subject to a superior power, but that power cannot come from an economic policy outlined by the state. As it is well known, our sociologist assigns priority in that regulatory capacity of the economic life to the occupational groups properlyarticulated with the state. ${ }^{23}$

\section{Conclusion}

In Durkheim's theoretical apparatus between 1892 and 1893 to account for all the integrating mechanisms which are typical of modern societies, a triple characterization of the state specificity can be distinguished. Firstly, a modern state is defined by its increasing intervention within familiar and private contractual relations, which become more and more rigorously regulated to maintain the harmony between all the members of a society. Secondly, the state is distinguished because of its less and less despotic relationship with its individuals. The individual sphere and the field of action of the state, in other words, evolve together. Thirdly, the modern state has reduced its autonomous capacity to define crimes and sanctions in relation to the states that have historically preceded it. This loss of legal autonomy represents the other side of the

23 David Grusky together with other specialists in topics related to stratification and social inequality departs from Durkheim's idea about considering professional groups as a supportive way that counteracts anomic relationships (and he also adds, the overexploitation) to criticize both neo-Marxists who try to apply the category of classes to huge populations and the theorists who advocate the complete disappearance of the concept of classes. From his viewpoint, it is necessary to disaggregate the concept of class, that is, applying the distinctions of classes to occupational smaller groups instead of discarding it completely. In this respect, the following works should be checked: Grusky (2005), Grusky and Galescu (2005), and Grusky and Sørensen (2001). 
thesis that considers the state as a translator or a social thinking organ. He considers that the less autonomy it has, the better effectiveness because the state organ is closer to collective consciousness.

As a backdrop of all his thoughts, there operates a thesis according to which the state expresses a pre-existing solidarity which was generated spontaneously by different social fabrics with no political interference. Consequently, both the state and political actions are unable to solve the crisis that affects social cohesion. Said crisis can be overcome exclusively by some slow automatic processes of regeneration of solidary contacts.

To result in this imperative social solidarity, the division of labor must be regulated by a right and a moral. Is that law a prerogative of the state? No, it is not. The generation of those common ideas and feelings, necessary to scaffold any society and the construction of a secular morality that fills the vacuum of a religious moral, corresponds in these years to professional groups.

In his analysis of a modern family as a marital association that is no longer able to fulfil the economic and moral functions it used to have, Durkheim (1892b) suggests facing the crisis through strengthening professional groups since he thinks that a professional may perform an integrating role similar to the one that a family used to have.

Continuously questioning the problem of the state and politics from the point of view of integration, Durkheim is solidly persuaded that the state instance does not have an important role in the resolution of the national crisis around 1893.

Lacroix (1981) takes the position held by the French intellectual in his thesis of 1893 with the name of geographic materialism, since the social phenomena studied there depended on the population's growth. Indeed, the historical genesis of the state is also determined by the phenomenon of dynamic density, which allows the transformation of primitive societies made up of simple segments in others, where differentiated organs start to form the state. Determined by morphological phenomena, the modern state grows in volume and functions just because it must follow the pace of the division of labor.

Equality in the external conditions of a struggle that would enable an ideal social state characterized by the fact that social differences would reproduce exactly the natural individual ones, is not unattainable for Durkheim under capitalist conditions. According to his words, in contemporary societies, there is a tendency for inequality of external conditions to become balanced. Some of these external conditions may be: the hereditary transmission of wealth, caste systems, the elitist access to certain university careers or to certain jobs, among others. 
The position that claims that the state must not interfere actively on the economic world is supported in a naturalization of social inequalities by reducing them to individual inequalities and in considering the social economic field as an area of healthy competition that does not admit interventions. For Durkheim, organic solidarity is deployed when spontaneity reigns in the external conditions of the struggle.

Equality between competitors must be wisely combined with discipline. For Durkheim, there is no society without discipline, without limitations of the individual aspirations, that are always disproportionate in relation to possible satisfactions. In conclusion, he hopes that the growing of equality occurs spontaneously, without the state's intervention and without a mass mobilization. His concern for the French separation does not derive in political activism but in the defence of moral education as a means of installing nationalism and respect for the established laws.

There is no room for political action: everything is determined beforehand by the society's morphology. Overcoming the crisis depends completely on the reestablishment of the spontaneous consensus of all its members.

He does not believe that the stability of modern societies depends on an economic basis. From his reading of the socialist doctrine, Durkheim concludes that industrial and commercial relations are not ordered following market rules and that they must be subject to moral forces that regulate them and show them a higher purpose.

Instead of the minor role that the state had in De la division du travail social, it now has a new dignity: connecting and integrating the disorganized and dispersed economic activities. The harmful and undesirable state's intermediation became a necessary tendency to the order of things in Durkeim's analysis on socialism.

Can we conclude then that Durkheim begins to value the state as a supreme instance of social integration? Absolutely not. Although he admits in his studies about socialism the role of the state as a growing intervention in the economy, he does not give to the state the privilege of being an integrating influence and, therefore, moral. It continues being, basically, a translator, an appendix of solidarities that overflows it.

Some years later the problems of the state and politics will regain certain importance. The last chapter of Le suicide (1897), the Préface de la seconde édition de la division du travail social (1901) and the Leçons de sociologie (1890-1900) ${ }^{24}$ contains precise instructions about the limitations of the state coercive policies to regenerate social fabrics. Besides, he also talks about the integrating and regulating

24 These lessons constitute the last edition of some courses given in 1890 and 1900 in Burdeos and repeated in Sorbonne in 1904 and 1912. The first three chapters of these lessons, referred to professional moral were published by Marcel Mauss in 1937. The whole text, including the lessons on the state, was ultimately known in 1950 from a publication made by Istanbul University on the base of the original manuscripts of the definite text from the lessons dating back to years 1899-1900 (Kubali, 1950). 
role that professional associations should perform and they are conceived as conveyor belts of the state organ representatives of general interest, in the moral crisis that modern societies are experiencing.

Faced with the threat of disintegration, Durkheim will insist on dismissing the solutions centered in traditional political institutions, such as political parties, the parliament and political leaders. He claims for the internalization of an integrating secular moral through the already mentioned professional groups subordinated to the state and the rational secular educational system. The state schools, guardians par excellence of our national type, as Durkheim will call them in his courses about L'éducation morale. (1899-1902), will appear as privileged spheres of the formal education of moral individuals.

Meanwhile, in other works, for example in the article Deux lois de l'évolution pénale (1900-1905) and in the course about L'État (1900-1905) ${ }^{25}$, Durkheim will advance in the distinction between democracy and absolutism and recognize that the role of the state is not limited to express and summarize the impulsive thinking of a multitude but to conform "a power station" of rational and meditated representations with a certain directive power.

Later, religious problems will become gradually more hegemonic than political interrogations about Law, the state, professional associations, socialism, etc. Although it constitutes a complex process, it can be said that from 1902 the question for political power will begin to vanish and only war will give him grounds for some last reflections about national states (Inda, 2008).

Grant Support: The author received no financial support for this work.

\section{References}

Alexander, J. (1982). Theoretical logic in sociology. The antinomies of classical thought: Marx and Durkheim. Berkeley, CA: University of California Press.

Bellah, R. (1973). Introduction. In R. N. Bellah (Ed.), Emile Durkheim: On morality and society (pp. 9-14). Chicago, CA: University of Chicago Press.

Birnbaum, P. (1976). La conception durkheimienne de l'État: L'apolitisme des fonctionnaires. Revue Française de Sociologie, 17(2), 247-258.

Challenger, D. (1994). Durkheim through the lens of Aristotle: Durkheim, post modernist and communitarian responses to the enlightenment. Maryland, MD: Rowman \& Littlefield.

Cladis, M. S. (1992). A communitarian defense of liberalism: Emile Durkheim and contemporary social theory. Stanford, CA: Stanford University Press.

Derek, S. (1991). Capitalism and modernity: An excursus on Marx and Weber. New York, NY: Routledge.

25 Course given between 1900 and 1905 and published posthumously in 1958 in the Revue philosophique. 
Durkheim, E. (1888). Cours de science sociale (Leçon d'ouverture). Revue internationale de l'enseignement, $X V, 23-48$.

Durkheim, E. (1893c). Note sur la définition du socialisme. Revue Philosophique XXXVI, 506-512.

Durkheim, E. (1934). L'éducation morale. Paris, France: Librairie Félix Alcan. (Original work published 1902-1903)

Durkheim, E. (1950). Leçons de sociologie: Physique des møurs et du droit. Paris, France: Les Presses universitaires de France. (Original work published 1890-1900)

Durkheim, E. (1966). La contribution de Montesquieu à la constitution de la science sociale. In E. Durkheim (Ed.), Montesquieu et Rousseau, précurseurs de la sociologie (pp. 25-113). Paris, France: Librairie Marcel Rivière et Cie. (Original work published 1892)

Durkheim, E. (1967b). De la division du travail social. Paris, France: Les Presses universitaires de France. (Original work published 1901)

Durkheim, E. (1967a). Le suicide. Étude de sociologie. Paris, France: Les Presses universitaires de France. (Original work published 1897)

Durkheim, E. (1969). Deux lois de l'évolution pénale. In Journal Sociologique (pp. 245-273). Paris, France: PUF. (Original work published 1899-1900)

Durkheim, E. (1969). Les études de science sociale. Revue philosophique, XXII. In E Durkheim (Ed.), La science sociale et l'action (pp. 61-80). Paris, France: PUF. (Original work published 1886)

Durkheim, E. (1975). L’État. In E. Durkheim (Ed.), Textes 3. Fonctions sociales et institutions (pp. 172-178). Paris, France: Les Éditions de Minuit. (Original work published 1900-1905)

Durkheim, E. (1975a). La philosophie dans les universités allemandes. In E. Durkheim (Ed.), Textes 3. Fonctions sociales et institutions (pp. 437-486). Paris, France: Éditions de Minuit. (Original work published 1887)

Durkheim, E. (1975b). La science positive de la morale en Allemagne. In Durkheim, E. Textes. 1. Éléments d'une théorie sociale (pp. 267-343). Paris: Éditions de Minuit. (Original work published 1887)

Durkheim, E. (1975c). Communauté et société selon Tönnies. In E. Durkheim (Ed.), Textes 1. eléments d'une théorie sociale (pp. 383-390). Paris, France: Éditions de Minuit. (Original work published 1889)

Durkheim, E. (1975d). La famille conjugale. In E. Durkheim (Ed.), Textes 3. Fonctions sociales et institutions (pp. 35-49). Paris, France: Éditions de Minuit. (Original work published 1892)

Durkheim, E. (1975e). Origine de l'idée de droit. In E. Durkheim (Ed.), Textes 1. Éléments d'une théorie sociale (pp. 233-241). Paris, France: Éditions de Minuit. (Original work published 1893)

Durkheim, E. (1992). Le socialisme. Sa définition. Ses debuts. La doctrine Saint-Simonienne. Paris, France: PUF. (Original work published 1895-1896)

Favre, P. (1982). L'absence de la sociologie politique dans les classifications durkheimiennes des sciences sociales. Revue Française de Science Politique, 32(1), 5-31.

Filloux, J. C. (1976). Il ne faut pas oublier que je suis fil de rabbin. Revue Française de Sociologie, 17(2), 259-266.

Filloux, J-C. (1977). Durkheim et le socialisme. Droz, France: Genève-Paris.

Fournier, M. (2007). Émile Durkheim, 1858-1917. París, France: Fayard. 
Giddens, A. (1979). Durkheim's political sociology. In A. Giddens (Ed.), Studies in social and political theory (pp. 235-273). New York, NY: Routledge.

Giddens, A. (1986). Durkheim on politics and the state. Stanford, CA: University Press.

Grusky, D. (2005). Is Durkheim a class analyst? In J. Alexander \& P. Smith (Eds.), The Cambridge companion to Durkheim (pp. 322-359). Cambridge, UK: Cambridge University Press.

Grusky, D., \& Galescu, G. (2005). Foundations of a Neo-Durkheimian class analysis. In E. Wright (Ed.), Approaches to class analysis (pp. 51-81). Cambridge, UK: Cambridge University Press.

Grusky, D., \& Sørensen, J. B. (2001). Are there big social classes? In D. Grusky (Ed.), Social stratification: Class, race, and gender in sociological perspective (pp. 183-194). Boulder, CO: Westview Press.

Hawkins, M. (1981). Durkheim, Emile on democracy and absolutism. History of Political Thought, 2(2), 369-390.

Inda, G. (2007). La sociología política de Émile Durkheim: La centralidad del problema del Estado en sus reflexiones del período 1883-1885. Andamios. Revista de Investigación Social, 4(8), $135-168$.

Inda, G. (2008). La interrogante política en Émile Durkheim: el abordaje del Estado moderno en la última fase de su producción (1897-1915). Revista Sociológica, 23(67), 109-148.

Joas, H. (1993). Durkheim's intellectual development: the problem of the emergence of new morality and new institutions as a leitmotif in Durkheim's oeuvre. In S. Turner (Ed.), Émile Durkheim: Sociologist and moralist (pp. 229-245). New York, NY: Routledge.

Kubali, N. (1950). Avant-propos de la première édition. In E. Durkheim (Ed.), Leçons de sociologie: Physique des mours et du droit (pp. 5-8). Paris, France: Les Presses Universitaires de France.

Lacroix, B. (1981). Durkheim et le politique. Paris, France: Presses de la Fondation Nationale des Sciences Politiques.

Lukes, S. (1985). Emile Durkheim: His life and work: A historical and critical study. Standford, CA: Standford University Press.

Mauss, M. (1928). Introduction. In M. Mauss (Ed.), Le socialisme. Sa définition. Ses debuts. La doctrine Saint-Simonienne. Paris, France: Librairie Félix Alcan.

Nicolet, C (1982). L'idée républicaine en France (1789-1924). Paris, France: Gallimard.

Ottonello, R. (2016). Lo leído y lo por leer en la sociología de Émile Durkheim. Perspectivas y clausuras tras un siglo de lecturas. Documentos de Jóvenes Investigadores, 43, $13-65$.

Rosanvallon, P. (2004). Le modèle politique français, la société civile contre le jacobinisme de 1789 à nos jours. Paris, France: Le Seuil.

Spitz, J.-F. (2005). Le moment républicain en France. Paris, France: Gallimard.

Watts Miller, W. (1997). Durkheim and Montesquieu. In E. Durkheim (Ed.), Montesquieu. Quid Secundatus Politicae Scientiae Instituendae Contulerit (W. Watts Miller, Trans., pp. 83-129). Oxford, UK: Durkheim Press. 